\title{
THE TRIDIMENSIONALITY OF MYTH IN TOLKIEN
}

\author{
From “Mitos em Três Dimensões" in Explicando Tolkien [Explaining Tolkien] \\ by Ronald Kyrmse - translated by the author
}

I believe every reader of Tolkien will agree with me when I say that the world created by him is uncommonly credible, fascinating and absorbing. Indeed we should not speak about creation, but rather about sub-creation. One text from the Professor that sheds some light on how he himself viewed the craft of a fantasy author is the talk "On Fairy-stories", given by him at the University of St Andrews on 8 March 1939, which was later published in book form together with other texts (The Monsters and the Critics and Other Essays). In this essay Tolkien distinguishes between Creation of the Primary World, the one we live in, the work of a supernatural Creator, and sub-creation of a Secondary World. This last is the product of an author's imagination, and we often see its like in fairystories.

Another explanation is due here; It is not necessary for a fairy-tale to be about fairies. This is only a convenient label for all works of fiction that approach or use a Secondary World for its characters to live adventures in. Not any secondary World: science fiction has created plenty of worlds for us without fairy-stories being the result. It is necessary, in the genre that interests us, that the secondary World be within or on the boundaries of what Tolkien calls Faërie: The Perilous (or enchanted) Realm. Not even Tolkien himself, in an essay written expressly to talk about fairy-tales, wanted (or was able) to define them. For him, as he said in his talk, Faërie "cannot be caught in a net of words; for it is one of its qualities to be indescribable, though not imperceptible". The Secondary Worlds we, who are enchanted by his work, deal with contain many narrative modes: fantasy, satire, allegory, moral tales... But they are typified mainly by Magic. Not, says Tolkien, artificial and scientific magic (Arthur Clarke, the author of 2001 and other science-fiction works, says that any sufficiently advanced technology is indistinguishable from magic), but rather a magic diametrically opposed to it. But, although magic is part of the Secondary World, we must believe in it, seriously, as a parcel of that world's laws. Still quoting Tolkien, "one thing must not be made fun of, the magic itself".

Referring more closely to the work of the author, Tolkien says - still in the abovementioned essay - that his art, correctly applied to the Secondary World, produces Secondary Belief. In other words: the more skilful the author, the more easily we will believe (if we are so inclined) what we describes for us, the better we will able to "enter" his world and so enjoy the tale as is it affected us directly, in our Primary World. This art, or "elvish craft", Tolkien calls Enchantment. "Enchantment produces a Secondary World into which both designer and spectator can enter, to the satisfaction of their senses while they are inside".

Therefore we see how complex is the "craft" of the author whose intention it is to convince us of the reality - conceived in a certain form, and for the ends of the story he is telling - of his world. This is a task Tolkien carries out successfully. I do not say easily: his stop-and-go mode of work, his sleepless nights, his never-ending revisions, his struggles for internal consistency, his endeavours to "authenticate" his world are well known. But success is patent, or else J.R.R. Tolkien would not have been called the "author of the 
century", nor would The Lord of the Rings have sold more than any other English-language book except for the Bible. What, then, is so peculiar in Tolkien's sub-creation that we fall in love with it, sometimes at first sight, and get lost (or found!) inside it, some of us for the rest of our lives?

On one hand, these tales constitute a myth. According to the author himself, myths are not lies, but sub-created realities. Myths are not meant to make the reader understand their meaning rationally, as being something shown and explained, but rather to have him find the concepts by himself, living them first-hand. Through myth we may experience directly the perils of adventure, good and evil, without putting our spiritual balance at risk. This is not a matter of "escapist literature": Tolkien distinguishes clearly between the escape of the prisoner and the flight of the deserter. The former is necessary to give us a clearer vision - "from the outside", so to speak - of our own reality, and the latter only renders us alien to the world. The quality of myth, for Tolkien, lies in the fact that it conveys to us fundamental and eternal truths in a form easy to assimilate. It was because he missed specifically English myths that he set out to

make a body of more or less connected legend, ranging from the large and cosmogonic, to the level of romantic fairy-story - the larger founded on the lesser in contact with the earth, the lesser drawing splendour from the vast backcloths [...] The cycles should be linked to a majestic whole, and yet leave scope for other minds and hands, wielding paint and music and drama. [The Letters of J.R.R. Tolkien - Letter 131]

Another word may answer the question about the fascination of Tolkien's work, a word that - let it be said - is neither short nor understandable without explanation: tridimensionality. The world which Tolkien sub-created has three dimensions that produce its appeal. It is obvious that to speak of dimensions is something one does at one's own will, at one's own risk: any one of us may focus on some feature of his object of study and call that a dimension. Dimensions in fact, though - this I learned from mathematics - must possess some minimal extension and independence. I explain: a point has no dimension; what I call dimension must contain many distinct points, each one individual by itself. And from each one of these points it must be possible to move in another direction, keeping some of the coordinates and varying others. Thus it is with length, width and height, which we consider intuitively as the three spatial coordinates. Each one may vary at will, but once we have fixed (say) length, we are free to move along height or width, potentially reaching every point in space.

So what are (the impatient reader asks) the three dimensions of Tolkien's world? Let us explore them one by one. 


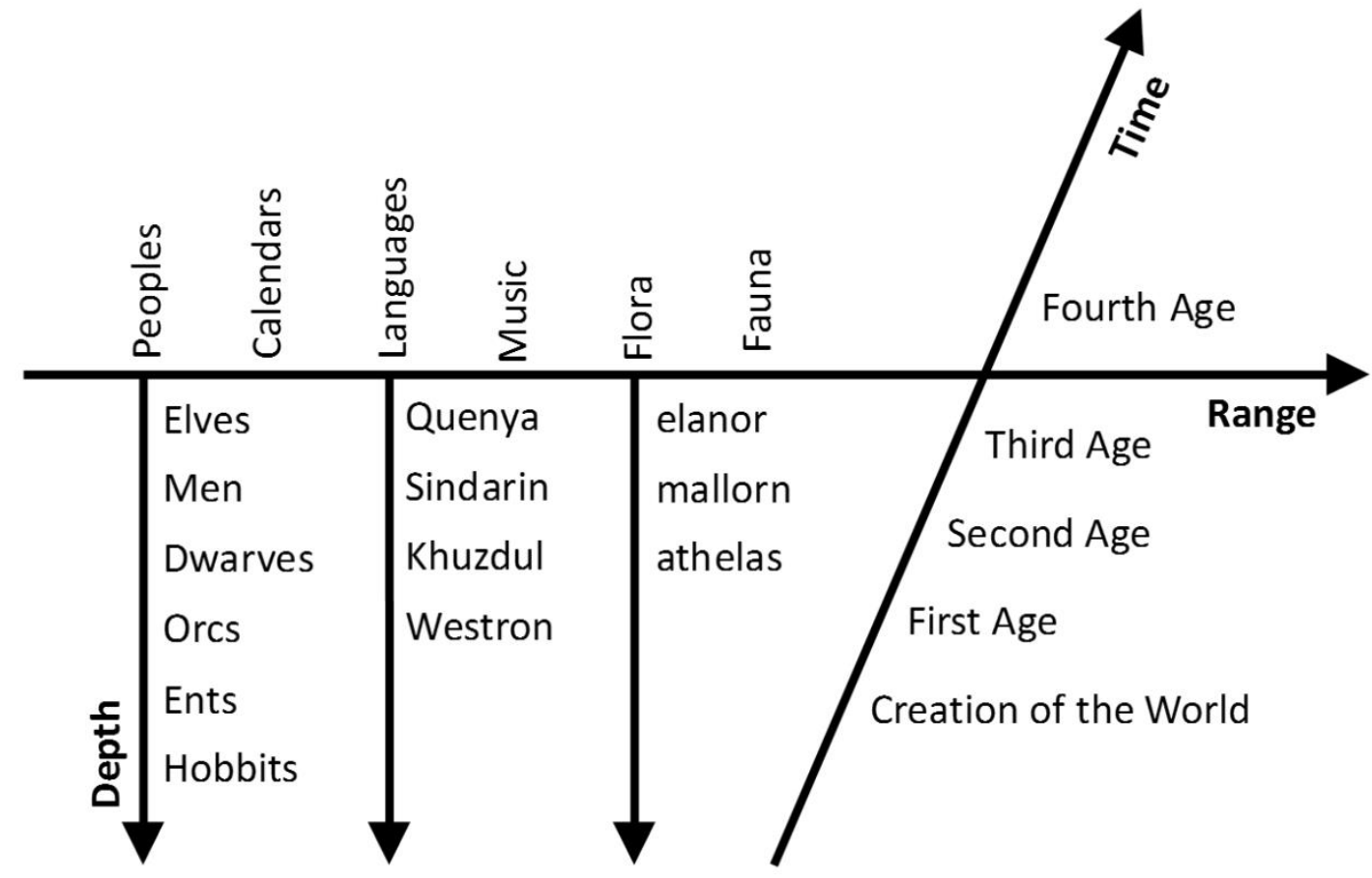

Range - Even if we read only The Hobbit, a work not composed with much ambition, meant to be read by children, we nevertheless see that the author deals with very heterogeneous matters. In his world he introduces us to different peoples and landscapes, and varied terrains, to customs that differ according to region, also to clothing, languages, beliefs, calendars... Even though some of these themes are dealt with superficially, as often happens in a tale whose interest lies further ahead, and which therefore has no time to dwell on such subjects, we perceive all the same that Tolkien has something to say on each of them, and that he does not say all he knows. This Secondary World is not a mere map on which characters move and live their adventures. It is not a mere collection of dwarves, elves, hobbits and other curious races. It is not simply a string of stories the characters tell, some older and others recent, about their ancestors or the heroes of the past. It is all this and much more. We gain the impression that no theme has been neglected by Tolkien: he knows the anthropology, botany, geology, fauna and flora, history and myths, languages, ethics, beliefs, even the modes of address of the world that he shows us. No theme escapes him - and this impression is confirmed as we delve more deeply into the Professor's works. Range, therefore, is the extension of subjects that give support and credibility to the Tolkienian world.

Depth - Beyond wandering on the line that includes all these modes of knowledge, we may begin to excavate details about each one of them. And we will succeed: no matter on what point of the range dimension we decide to dig, there will always be something in the underground. Let us take as example the languages - admittedly one of Tolkien's passions since his childhood. For some minor author it would have been an easy matter to put into his characters' mouths exotically-sounding words, only in order to infuse the tale with an ait of strangeness. Nothing is easier than saying "ondo is stone, alda is tree, and we're set". But these are precisely the words that designate "stone" and "tree" in Quenya, 
one of the Elvish languages Tolkien created. Apart from this one, also known as High Elvish, there is Grey Elvish or Sindarin, possessing its own vocabulary, its complex grammar and its quite peculiar phonology. Besides these languages we catch glimpses of others from the same family; and not only were the languages of the Elves sub-created, but also those of the various groups of Men, that of the Dwarves, of the Orcs and others still. When a character greets another saying Elen síla lúmenn' omentielvo, we may be sure that each word is analyzable according to case, tense, person and its constituent phonemes, and that all these rules are recorded somewhere. When we traverse a plain named Dagorlad, that is not an arbitrary sound; it has meaning and history. What I have detailed for linguistics is also true, in greater or lesser degree, in geology, politics, heraldry and other subjects. It is precisely the fact that the backdrops are not cardboard, that the characters are not mere puppets, which confers solidity to this Secondary World.

Time - Beyond presenting to us an ample and detailed world, where each object withstands scrutiny through a magnifying lens, J.R.R. Tolkien adds the temporal dimension. When the characters ford a river we are sure that the watercourse has not been put there only to serve as an obstacle or a convenient means of transport. It has been flowing through that place for millennia and is mentioned on maps and ancient records. It has been the stage of events which, even if not recounted in that passage, may be part of another of Tolkien's texts. The Elves - immortal while they suffer no unbearable physical or emotional shock - are themselves the personification of time. In The Lord of the Rings, set during the end of the Third Age, there appear characters whose story we may follow since the First Age, many millennia before. The Silmarillion begins with the creation of the world and follows families, migrations and dramas along thousands of years. Also behind every hill, every cove there exists a panorama of vast temporal extensions, of years únótimë ve rámar aldaron - uncountable as the wings of trees.

In each object of sub-creation the three dimensions are manifest. Let us take a point on the range dimension and we shall see that the very legends told by each people have deserves Tolkien's intense attention. They take up a place on the rage line next to each people's dress, of its beliefs, of its peculiar mode of building... One of these stories - and here we enter into the depth of the "legends" theme - about the human race is the "Narn $\mathrm{i}$ Hîn Húrin", the "Tale of the Children of Húrin". Time becomes manifest when Elrond, in The Lord of the Rings, refers to the story of Húrin and his son Túrin, as something very ancient that his listeners already know from lore. Also the fact that the "Narn" exists in different versions - in prose and in verse, earlier and later - conveys to us the feeling of a long narrative lineage, stemming maybe from different authors and diverse approaches within the Secondary World,

It is pleasant to abandon our Primary World for some time and delve into the Secondary, when the latter is constructed thanks to a true "elvish craft", with a vision so encompassing and at the same time so thorough, while being conscious of the fact that even an imaginary world must have a history to explain it. Tolkien's is so complex that we can at will perceive it as a mere environment for the tale, always supporting it and lending it consistency, or else we can undertake to analyse it and thus become linguists, geographers, botanists or military historians of Arda, the Tolkienian world. This has been the approach of many scholars. 
The world of Arda bears a relationship of equivalence with ours. It is certainly the secondary World best worked out - along more than half a century - by a single individual, at once generalist and detail-loving. It is so different from our Primary World that we may experience wonder while we visit it, and it is at the same time so similar that the ideas and lessons it shows us - as is fitting to myths - may be applied to our own lives today.

Bibliography

Kyrmse, R.E. (2003). Explicando Tolkien. São Paulo: Martins Fontes.

Tolkien, J.R.R. (1981). The Letters of J.R.R. Tolkien. London: George Allen and Unwin.

Tolkien, J.R.R. (1983). The Monsters and the Critics and Other Essays. London: George Allen and Unwin.

São Paulo, August 2020 